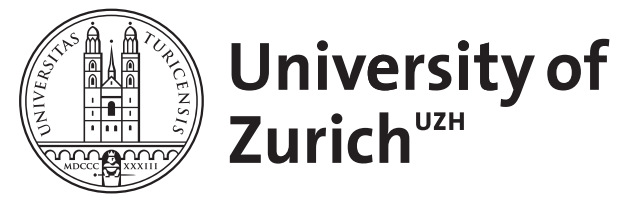
Archive

University of Zurich

University Library

Strickhofstrasse 39

CH-8057 Zurich

www.zora.uzh.ch

Year: 1964

\title{
Cervical Lymphography in Cases of Laryngo-Pharyngeal Carcinoma
}

Fisch, U P

DOI: https://doi.org/10.1017/s0022215100062678

Posted at the Zurich Open Repository and Archive, University of Zurich

ZORA URL: https://doi.org/10.5167/uzh-154513

Journal Article

Published Version

Originally published at:

Fisch, U P (1964). Cervical Lymphography in Cases of Laryngo-Pharyngeal Carcinoma. Journal of Laryngology and Otology, 78(08):715-726.

DOI: https://doi.org/10.1017/s0022215100062678 


\title{
The Journal of
}

\section{Laryngology and Otology}

(Founded in 1887 by Morell Mackenzie and Norris Wolfenden)

$$
\text { August I } 964
$$

\section{CERVICAL LYMPHOGRAPHY IN CASES OF LARYNGO-PHARYNGEAL CARCINOMA*}

\author{
By U. P. FISCH (Zurich) †
}

Irvolvement of the cervical lymphatic system is very often the major problem in evaluating the therapeutic approach for head and neck malignancies as the clinical methods available to determine the extent of metastatic spread from a particular tumour are limited.

The development of a technique for cervical lymphography has proved of great value in the functional study of the lateral cervical lymphatic system (Fisch and Sigel, I964). It was hoped that lymphography would also be of value in the observation of cervical metastases. For this reason, cervical lymphography has been performed in patients with head and neck malignancies and it is the purpose of this paper to describe the lymphographic patterns observed in cases of laryngopharyngeal carcinoma.

\section{Lymphographic technique}

\section{Method}

Oil-contrast material, lipiodol ultra-fluid, has been injected in a deep retro-auricular lymph vessel using a previously described technique (Fisch and del Buono, Ig63a).

* Read at the meeting of the Section of Laryngology of the Royal Society of Medicine on February 7 th, 1964.

$\dagger$ From the Department of Otolaryngology (Head: Professor L. Rüedi) of the Lniversity of Zurich, Switzerland. 


\section{U. P. Fisch}

\section{Selection of patients}

Cervical lymphography was performed on twenty consecutive patients with squamous-cell carcinoma of the larynx and hypopharynx prior to surgical therapy.

\section{Histologic technique}

Nodes filled with Lipiodol were identified by X-ray of the resected specimen. Using this $\mathrm{X}$-ray information and careful dissection, all visible and palpable nodes were removed from the specimen and divided into four nodal groups (junctional, jugular, supraclavicular and spinal) as previously established in non-pathologic cervical lymphograms (Fig. I). The lymph nodes were imbedded in paraffin and representative sections

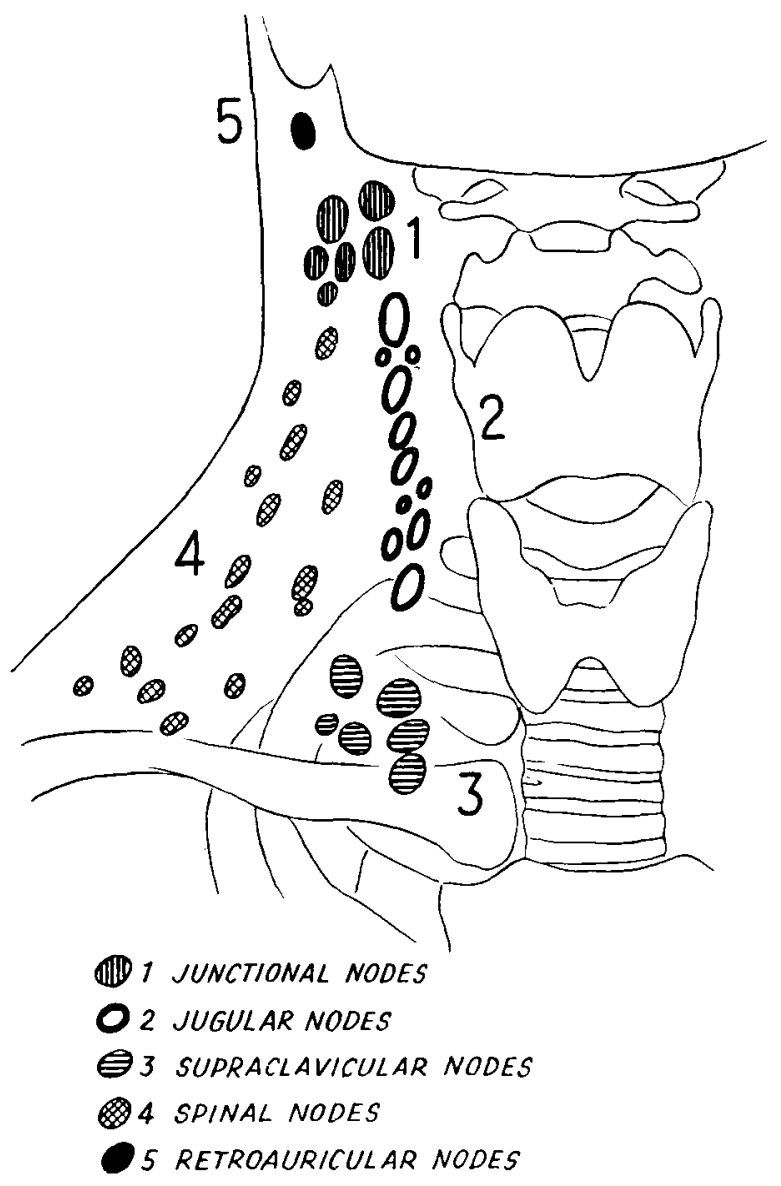

FIG. I.

Schematic-representation of the nodal groups in the cervical lymphatic system as visualized by lymphography (Fisch and Sigel, I964). 


\section{Cervical Lymphography in Laryngo-Pharyngeal Carcinoma}

stained with H. and E., Van-Gieson, Giemsa and Bielschowsky-Gomori techniques. In instances of questionable findings, serial sections of a lymph node were examined.

\section{Results}

From the twenty cases studied, three patients, illustrating the main patterns observed, are presented.

Case I. V.W., a 67-year-old white male, attended the O.R.L. Policlinic of the University of Zurich on February 14th, rg63, with a 3 month history of dysphagia. Physical examination revealed an exophytic lesion of the right aryepiglottic fold and two palpable lymph nodes in the region of the anterior superior border of the right sternocleidomastoid muscle. Direct laryngoscopy and biopsy revealed squamous-cell carcinoma. Cervical lymphography was performed prior to a right radical neck dissection-the patient having refused laryngectomy. The primary was treated by radiotherapy.

The cervical lymphogram (Fig. 2) revealed a complete block in the jugular and spinal chains whereas the junctional and supraclavicular nodal groups exhibited partial filling.

A schematic representation of the histologic examination is seen in Fig. 3. Four nodes in the upper jugular chain were invaded by carcinoma. In the region of the block, no tumour was present in 29 lymph nodes of the jugular and spinal chains. However, $2 \mathrm{I}$ of these 29 lymph nodes revealed a marked hyperplastic reaction either of the lymphatic type, reticular type, or both.

Case II. W.E., a 5 I-year-old white male, attended the O.R.L. Policlinic of the University of Zurich on May 29th, I963, with a history of progressive hoarseness over the preceding month. Physical examination revealed an ulcerating lesion of the right false cord. No lymph nodes were palpable. Direct laryngoscopy and biopsy revealed a squamous-cell carcinoma. Cervical lymphography was performed prior to laryngectomy and right radical neck dissection.

The cervical lymphogram (Fig. 4) revealed a total block of the right jugular chain whereas the junctional, supraclavicular and spinal groups were partially filled. A schematic representation of the histologic examination is seen in Fig. 5. No carcinoma was found in the resected lymph nodes. All the blocked lymph nodes of the jugular chain (I3 out of I3) $_{3}$ revealed a marked hyperplastic reaction, predominantly of the reticular type (9 out of I3).

The reticular reaction observed consisted in a proliferation of reticulum cells filling entirely the marginal and intermediate sinuses of the nodes (Fig. 6a). Fig. $6 b$ demonstrates the presence of an intricated network of fibrils around the reticulum cells filling the sinuses. 


\section{U. P. Fisch}
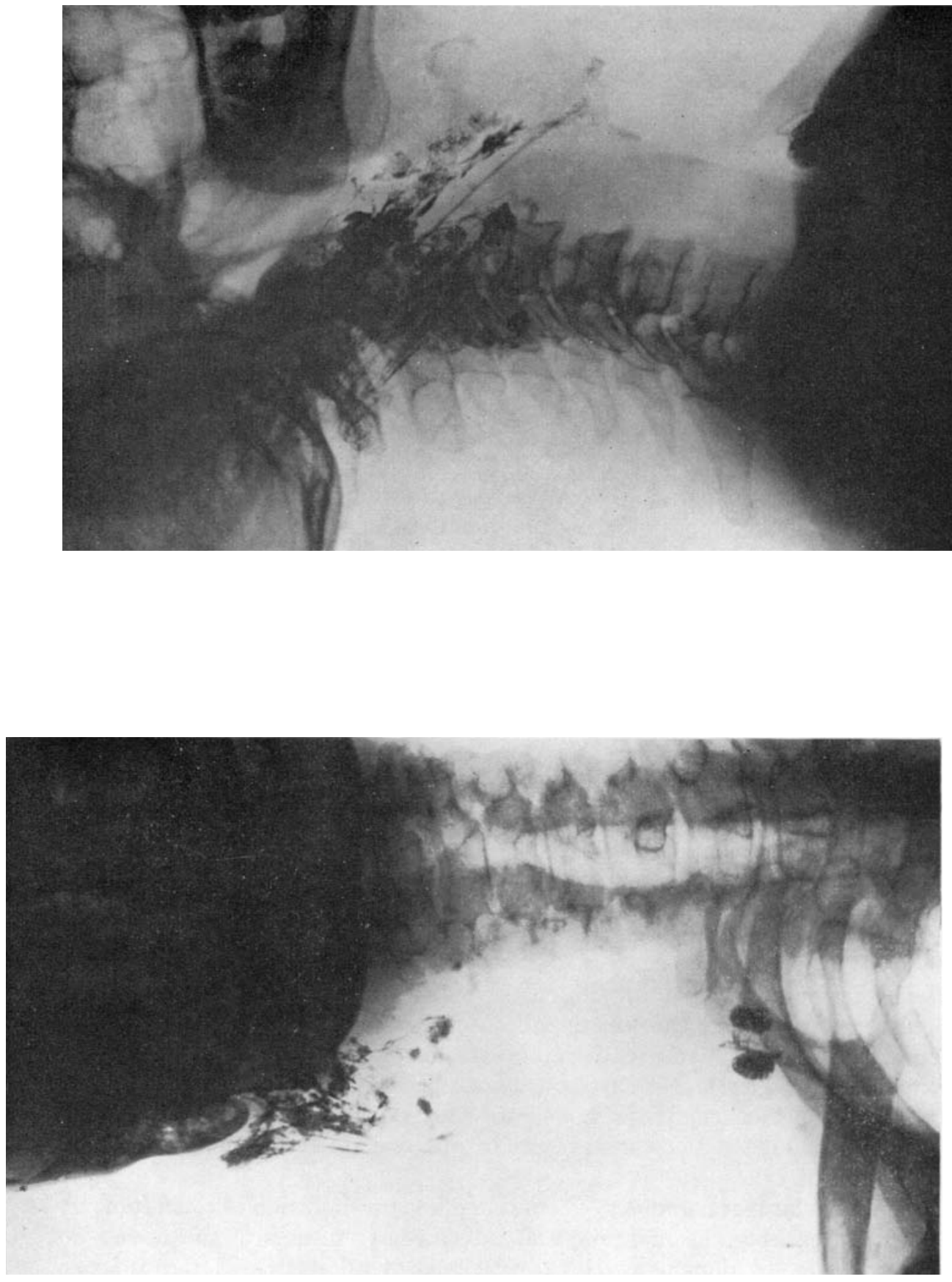


\section{Cervical Lymphography in Laryngo-Pharyngeal Carcinoma}

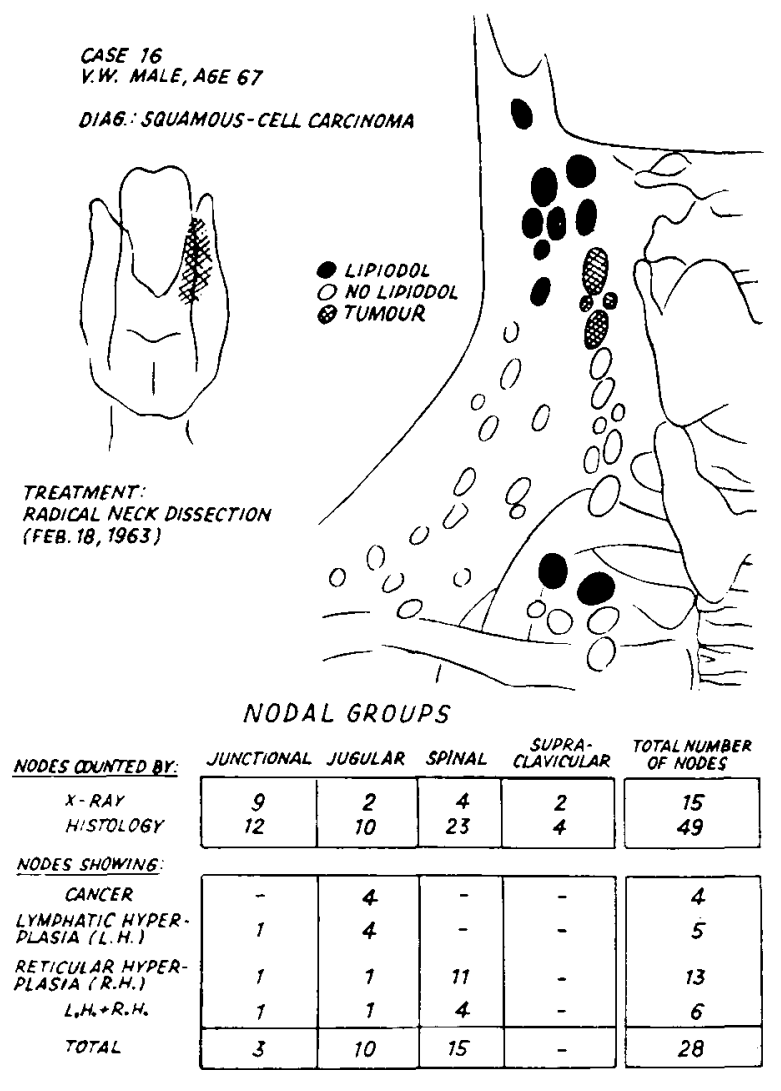

FIG. 3.

Case I: note the limited extent of the metastases in relation to the blocked lymph nodes.

Case III. C.E., a 4I-year-old white male, attended the O.R.L. Policlinic of the University of Zurich on April I6, I963, with a history of progressive hoarseness over the preceding seven months. Examination revealed an exophytic tumour of the fixed left vocal cord extending to the anterior commissure. No cervical nodes were palpable and squamous-cell carcinoma was found on biopsy. Cervical lymphography was done prior to laryngectomy and left radical neck dissection.

The cervical lymphogram (Fig. 7) reveals the junctional, spinal and supraclavicular nodes to be partially filled with contrast material The enlarged lymph nodes of the jugular chain are completely blocked. However, being surrounded by extravasated Lipiodol, they are recognizable by their outline. Sixty-two nodes were removed from the specimen and examined. A schematic representation of the histologic examination is seen in Fig. 8. No carcinoma was found in the cervical lymph nodes. All 


\section{U. P. Fisch}

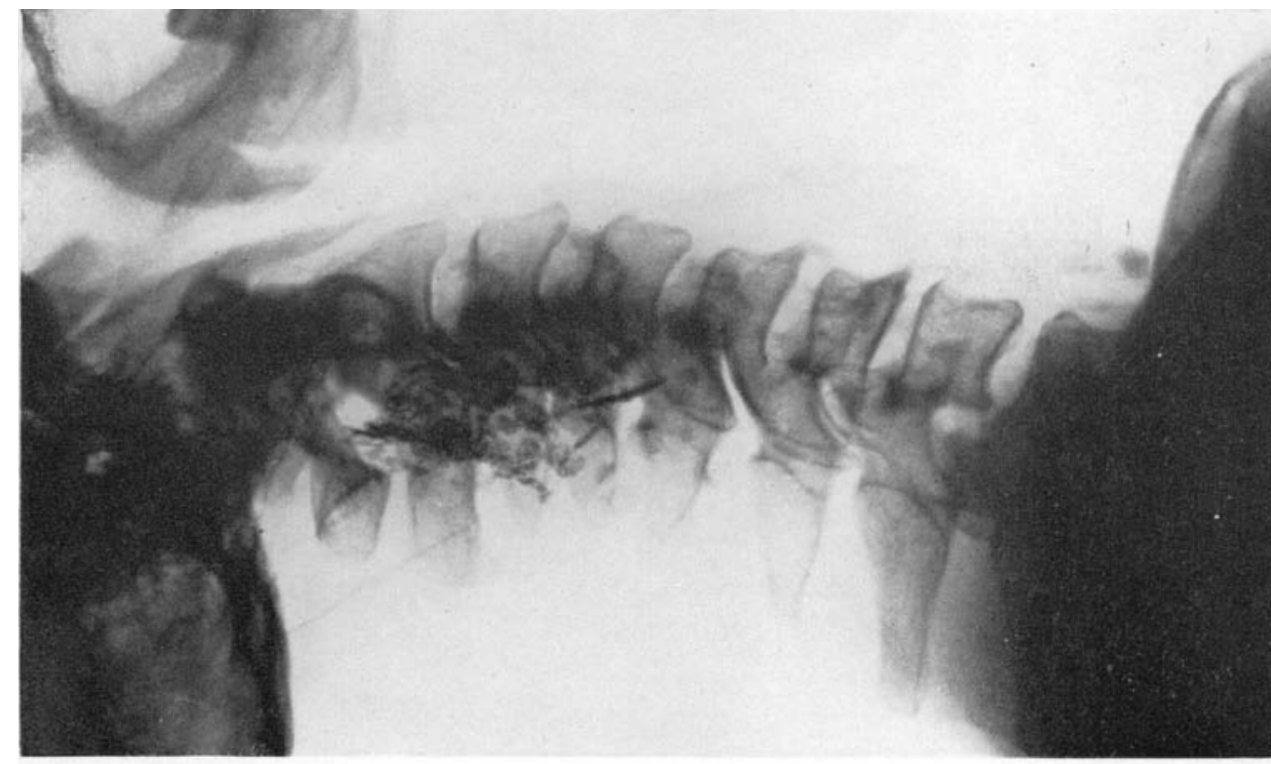

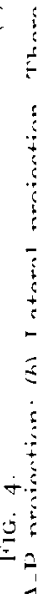

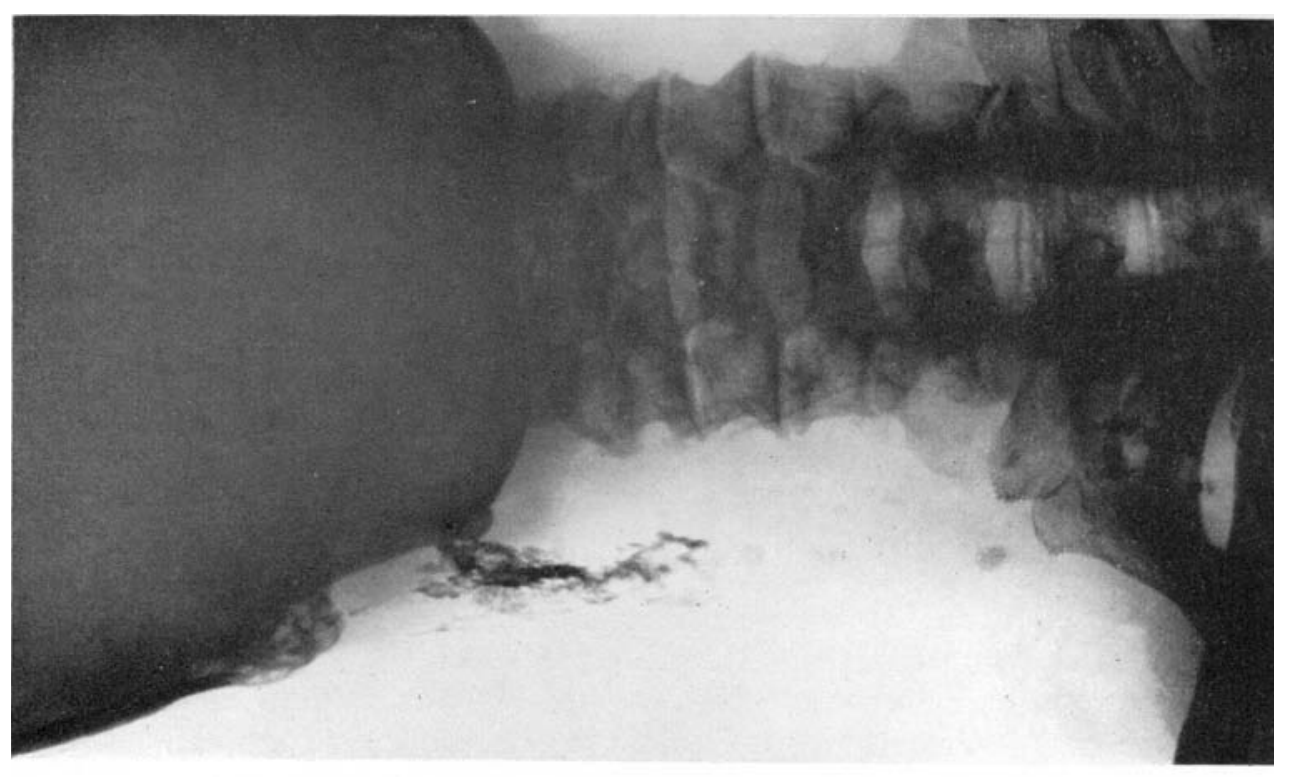

$\xi$

i

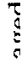

3

声

E

720 


\section{Cervical Lymphography in Laryngo-Pharyngeal Carcinoma}

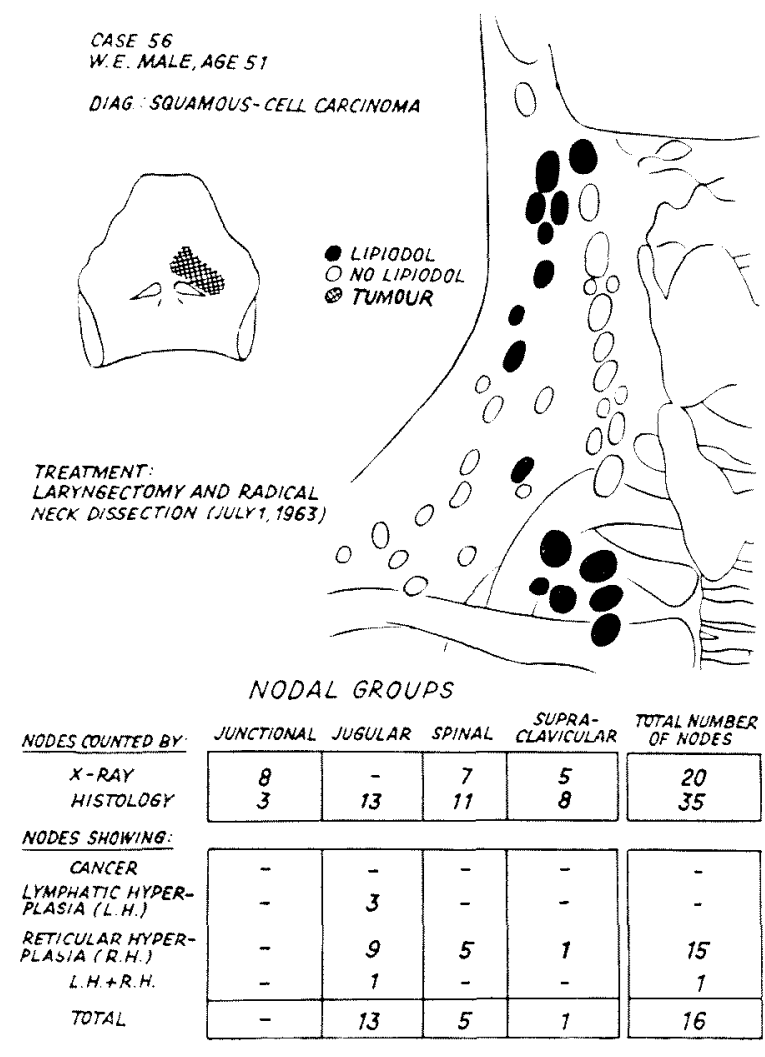

FIG. 5 .

Case II : note the absence of metastases in the blocked region.

the blocked nodes of the jugular chain (7 out of 7), revealed a follicular type of hyperplastic reaction. The enormously enlarged secondary follicles are seen in Fig. ga.

The compression of the marginal sinus by the hyperplastic pulp is demonstrated in Fig. $g^{b}$.

\section{Comment}

A block to oil-contrast material in the cervical lymphatic system has been observed in all twenty studied cases of laryngeal and hypopharyngeal carcinoma. In the blocked nodes of the first case, both cancer and a hyperplastic reaction were found. Cases II and III demonstrate, however, that a block in the lymphatic system does not necessarily imply the presence of metastatic carcinoma as a reticular or lymphatic hyperplasia of the cervical nodes alone produced a block in the lymphatic flow.

Even partial filling of a single node, which in the $\mathrm{X}$-ray picture has 


\section{U. P. Fisch}

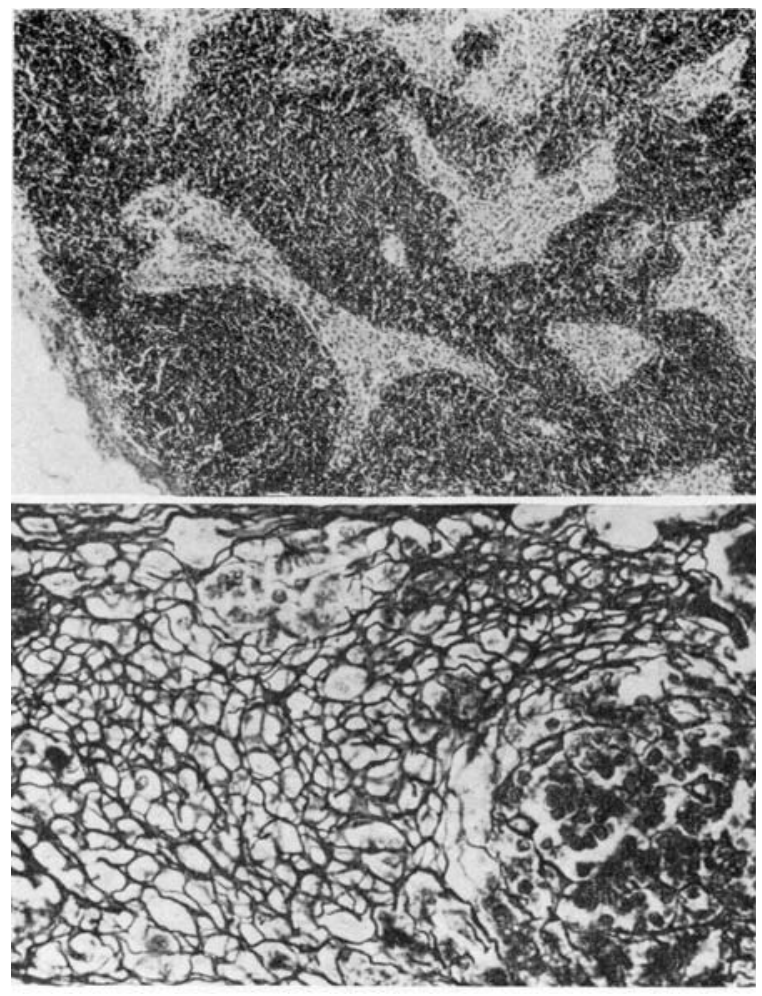

(a)

(b)

FIG. 6.

Case II: (a) Section of a jugular lymph node with a marked hyperplastic reaction of the reticular type in the intermediate sinuses (H.E. $\times 25)$. (b) Fibrillary network around proliferating reticulum cells in an intermediate sinus (Bielschowsky-Gomori $\times 160$ ).

been felt to be pathognomonic of cancerous invasion, is observed with this hyperplastic reaction alone (Fisch and del Buono, I963b).

As demonstrated in the silver stains, it is evident that the compact mass of reticulum cells and their fibrils, filling marginal and intermediate sinuses, may serve as sufficient obstacle to lymphatic flow through the lymph node. Compression of the sinuses resulting from the hyperplastic pulp and the diffuse massive lymphocytic infiltration observed in the instances of lymphatic hyperplasia may also account for this block.

It follows that we are not able, from the cervical lymphograms alone, to distinguish which type of pathologic change (tumour or hyperplastic reaction) is present in the blocked nodes.

For this reason, cervical lymphography alone cannot be used to prove the presence of metastases. Conversely, an absence of block or filling defects may exclude the presence of cancer in the filled nodes.

Further studies are necessary to determine the significance of these findings. It is interesting that Black and Speer (1958) observed a similar 
Cervical Lymphography in Laryngo-Pharyngeal Carcinoma

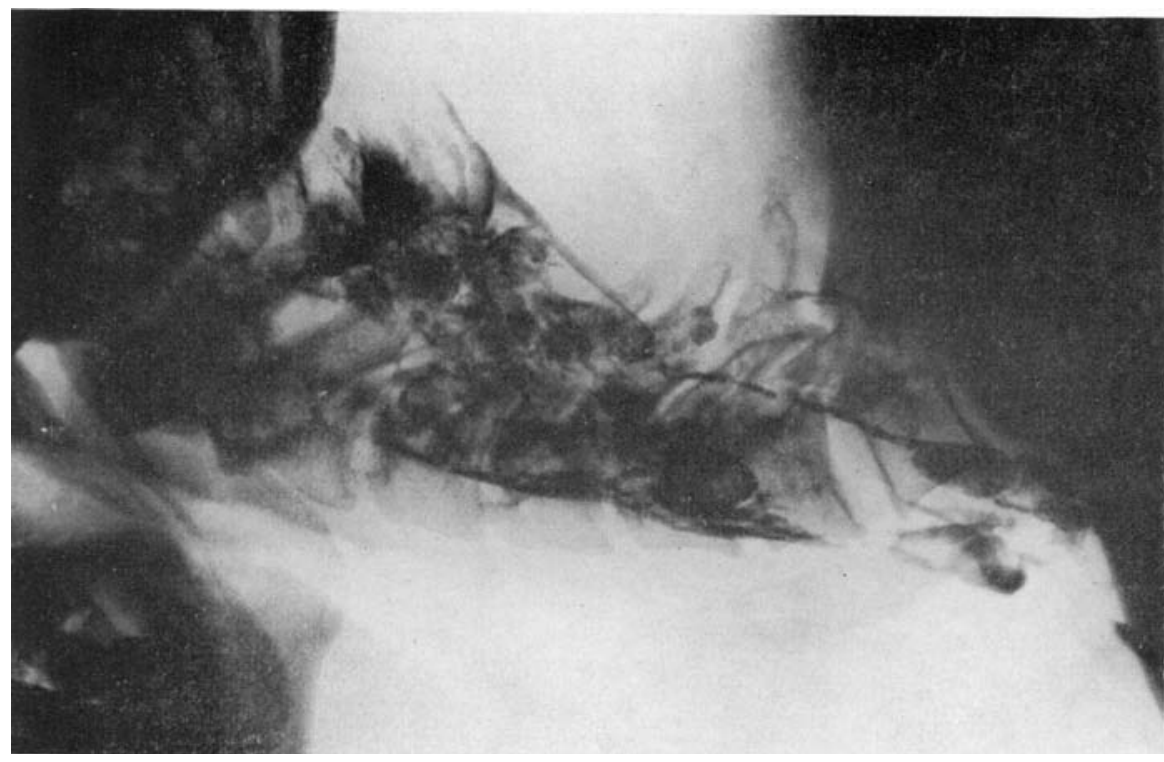

อ

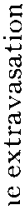

$\Xi$

$\stackrel{3}{5}$

롱

플

.

总兽

药

总总

홍

동

.

要

要

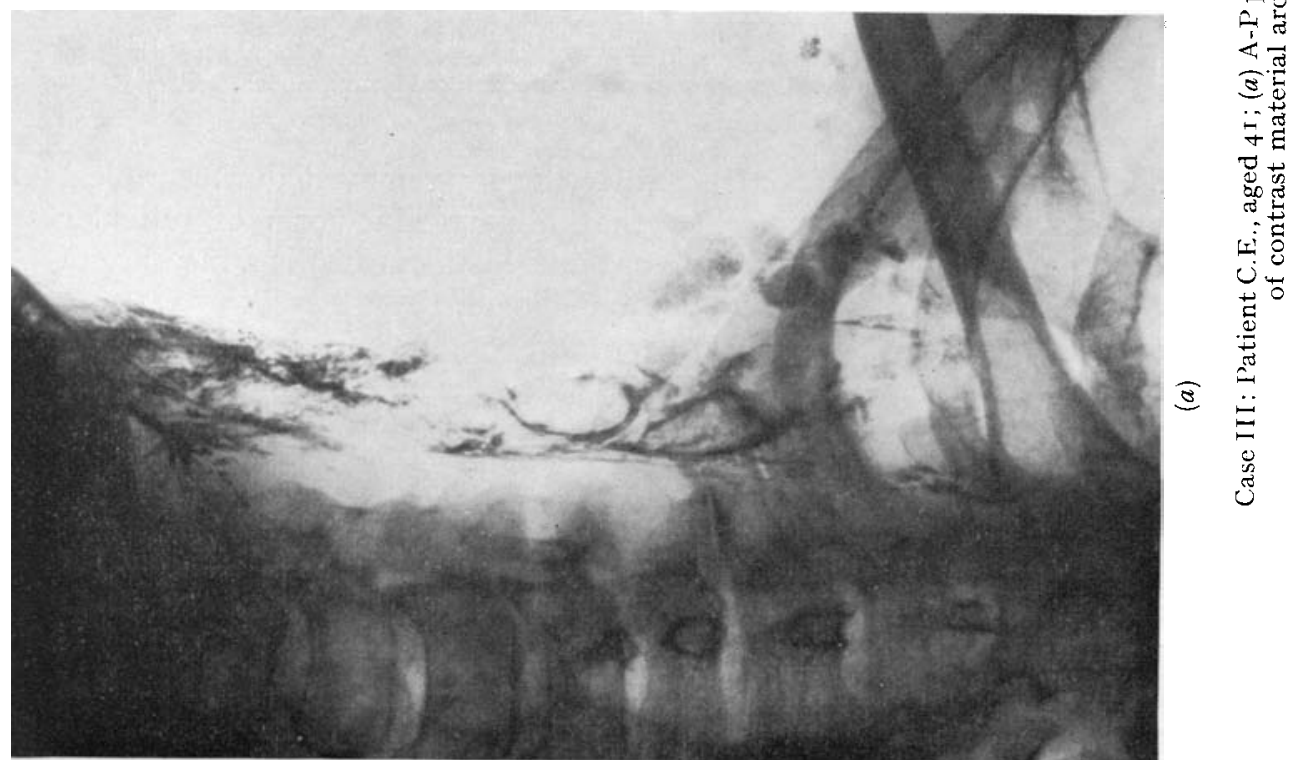




\section{U. P. Fisch}
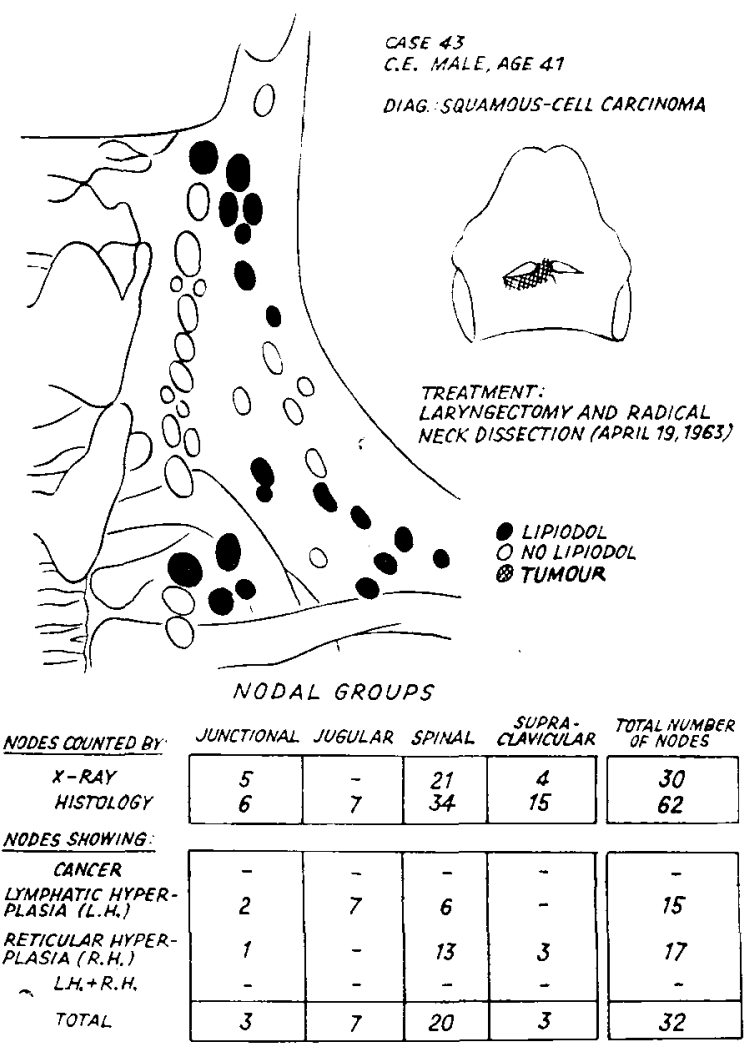

Fig. 8.

Case III: no metastases are present in the blocked lymph nodes.

type of hyperplastic reaction in axillary nodes removed during radical mastectomy. It was their feeling that a particular form of reticular hyperplasia (which they referred to as sinus histiocytosis) is a measure of the host resistance to cancer growth and spread.

At present, a block in the cervical lymphogram in cases of head and neck malignancies should be considered as suspicious for tumour invasion, and on this basis cervical lymphography may already be of clinical help.

\section{Summary}

The results obtained in twenty cervical lymphograms on patients with carcinoma of the larynx and hypopharynx are illustrated by three representative cases.

A block to oil-contrast material has been observed in all the studied cases. This block may be due to:

(I) Metastatic carcinoma. 


\section{Cervical Lymphography in Laryngo-Pharyngeal Carcinoma}

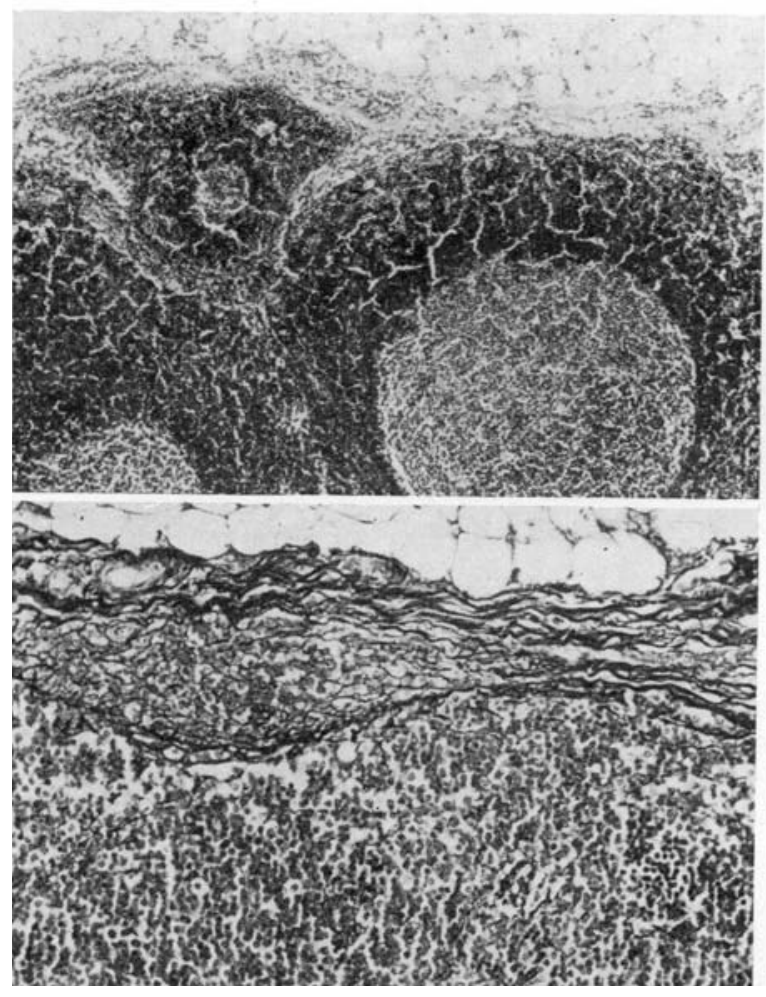

(a)

FIG. 9 .

Case III: (a) Section of a jugular lymph node with follicular hyperplasia (H.E. $\times 25$ ). (b) Compression of a marginal sinus by the hyperplastic pulp of the same lymph node (Bielschowsky-Gomori $\times 64$ ).

(2) Reticular hyperplasia of the lymph nodes.

(3) Lymphatic hyperplasia of the lymph nodes.

(4) Any combination of the above three pathologic changes.

A block in the cervical lymphogram does not necessarily imply the presence of metastatic carcinoma.

\section{Zusammenfassung}

Die Resultate von zwanzig cervikalen Lymphographien bei Patienten mit einem Carcinom des Larynx oder Hypopharynx werden anhand von drei typischen Beispielen demonstriert. In allen untersuchten Fällen wurde ein Block im cervikalen Lymphsystem für das olige Kontrastmittel festgestellt.

Der beobachtete Block ist auf folgende Ursachen zurückzuführen:

(I) Metastasen eines Carcinoms.

(2) Reticuläre Hyperplasie der Lymphknoten. 


\section{U. P. Fisch}

(3) Lymphatische Hyperplasie der Lymphknoten.

(4) Die Vereinigung zweier oder der drei obgenannten pathologischen Veränderungen.

Beim Vorkommen eines Blockes im cervikalen Lymphogramm kann man nicht ohne weiteres auf das Vorhandensein von Metastasen schliessen.

\section{Résumé}

Parmi vingt cas de lymphographies cervicales effectuées chez des malades présentant un cancer du pharynx ou de l'hypopharynx trois cas typiques sont mis en évidence.

Un blocage du système lymphatique cervical a été observé dans tous les cas étudiés. La cause de ce blocage peut-être:

(I) Une métastase de carcinome.

(2) Une hyperplasie réticulaire des ganglions.

(3) Une hyperplasie lymphatique des ganglions.

(4) La combinaison de deux ou des trois états sus-mentionnés.

On en conclut qu'un blocage observé dans un lymphogramme cervical ne prouve pas nécessairement l'existence de métastases cancéreuses dans les ganglions du cou.

\section{REFERENCES}

Black, M. M., and Speer, F. D. (1958) Surg. Gynec. Obstet., 106, 163.

Fisch, U. P., and del Buono, M. S. (1963a) Schweiz. med. Wschr., 93, 994. , and (1963b) Arch. Ohr.-, Nas.-, u. Kehlk.-Heilk., 182, 3I I. , and Siget, M. E. (1964) Ann. Otol. (St. Louis) (in press).

Dept. of Oto-Laryngology,

University of Zurich,

Zurich, Switzerland. 